Institute of Internet and Intelligent Technologies

Vilnius Gediminas Technical University

Saulètekio al. 11, 10223 Vilnius, Lithuania

http://www.isarc2008.vgtu.lt/

June 26-29, 2008

ISARC-2008

\title{
PERFORMANCE EVALUATION OF MELTING-BLOWN COLOR PAVEMENT METHOD
}

\author{
In-Kyoon Yoo \\ 2311, Daehwa-Dong, ilsanseo-Gu, Goyang-Si \\ Gyeonggi-Do, 411-712 Republic of Korea \\ Korea Institute of Construction Technology \\ Highway Facility Research Div. Director \\ www.kict.re.kr \\ Tel)+82-31-9100-167 Fax)+82-31-9100-161 \\ ikyoo@kict.re.kr
}

\author{
Soo-Hyung Lee \\ 2311, Daehwa-Dong, ilsanseo-Gu, Goyang-Si \\ Gyeonggi-Do, 411-712 Republic of Korea \\ Korea Institute of Construction Technology \\ Highway Facility Research Div. Researcher \\ www.kict.re.kr \\ Tel)+82-31-9100-144 Fax)+82-31-9100-161 \\ shlee1@kict.re.kr
}

\begin{abstract}
With the improvement in standard of living as well as economic growth, unlike the past, the importance of environmental and aesthetic aspects of construction structures is now greatly emphasized out of change of environment recognition. In particular, color pavement is generally applied to walks at park, sidewalk, bicycle path, parking lot and etc. in order to improve the appearance of cities. Similarly, as for roadway(car lane), color pavement is applied to crosswalk, road in front of school, section with high accident rate and etc. in order to inform clearly drivers of dangerous section. In addition, in order to smooth transportation, dark red color pavement is applied to bus lane which prohibits other cars except for bus from entering or no parking/stopping zone, and its application is expanding continuously.

Color pavement applied to roadway should meet requirements such as color retention, security of skid resistance and durability. However, current color pavement technique applied in Korea doesn't satisfy above requirements because of separation of aggregate, suspension of pigments, decoloration of surface and so on, accordingly cost of social loss has been increasing.

To solve these problems, construction technique should be developed for securing excellent construction property through workmanship and mechanization equipment to guarantee durability with innovative improvement of materials. Through this development color pavement technique should be secured corresponding to social needs.

Based on melting-blown road marking paint technique, this study examined manufacturing of advanced ultra-thin layer color pavement composite and construction technique which increases durability and skid resistance by mixing rubberbased resin and hard aggregates based on road marking paints, and evaluated performance of pavement technique suggested in this study. As a result, composite satisfied standard of quality in melt-type road marking paints, and skid resistance experimented before and after construction resulted that skid resistance was improved after construction (applying this composite). In addition, water permeability maintained more than $80 \%$ before and after applying meltingblown advanced ultra-thin layer color pavement, accordingly it is considered that there is no problem to maintain its function when applying it to porous pavement block.
\end{abstract}

\section{KEYWORDS}

Color Pavement, Melting Blown, Performance Evaluation 


\section{INTRODUCTION}

Economic growth and higher living standards have changed people's perception towards the environment. Naturally, both environmental and aesthetic aspects of construction structure are under greater spotlight, as opposed to the past.

For more aesthetic cityscape, walks in parks, walkways, bicycle paths and parking lots now have color pavements and even crosswalks, school zones as well as accident-prone road sections have color pavements to warn drivers against accidents. Furthermore, bus lanes prohibiting vehicles other than bus for smoother traffic flow and no parking/ stopping zones are covered with dark red color pavement. Indeed, the presence of color pavement around us is on the increase.

Yet, color pavement does not necessarily satisfy all the conditions, causing separation of aggregate, suspension of pigments and texture decolorization, which in turn incur greater social loss.

The solution to these defects lies in an advanced manufacturing technique to secure durability, higher quality materials, sophisticated construction technique that takes advantage of mechanization equipment to obtain superb construction property and it is through these new ideas that color pavement technique will live up to the social expectations.

This paper describes how composite for ultra-thin layer color pavement, which has been newly developed by a domestic manufacturer with basic reference to melting-blown paint technique for road marking, is manufactured and its construction technique. Latter part of the treatise will cover performance evaluation results of the pavement method employed with identical technique.

\section{STATUS OF EXISTING TECHNIQUE \& DEFECTS}

Color pavement is largely divided between mixingtype manufacturing and adhesion-type manufacturing. Mixing-type color pavement is manufactured either by using general aggregate and mixing colorless binder with pigments or mixing colorless binder and colored aggregate. In other words, mixing-type is a construction method where the asphalt mix itself is manufactured to produce a color.
Plants and construction equipment used for existing asphalt pavement may also be used for mixing-type color pavement. Adhesion-type manufacturing refers to applying color binder like skid resistance pavement on top of the existing pavement and binding color aggregate or coating spray color paint just like painting car lanes.

Color pavement in bus lanes in Korea employs a mixing method whereby pigments are mixed into transparent binder [1, 2]. This method, however, causes suspension of dark red pigments when rain drops fall and gather around in damage areas like pot holes as well as plasticity deformation in bus stops and stop lines in intersections where traffic load is heavy. Furthermore, abrasion in pavements and ultra-violent rays decolor pavements, of which study is currently underway to improve some of these major defects.

Anti-slippery pavement method, which is one of the adhesive-type color pavements, causes problems such as inefficient construction process due to high viscosity under low temperature, carcinogens in epoxy composite toner, which is a bonding agent, possibilities of surplus aggregate when distributing excess aggregate during construction, aggregate falloff due to bonding agent's weak adhesive strength. In addition, road evenness is considerably undermined and cracks in the existing pavements stemming from bonding agent's strong contractile force deteriorate durability.

Car lane painting method, which is frequently used for road marking, falls far behind other methods in skid resistance and thus is not qualified for application across roadways.

Despite such defects, demand for color pavement method is rapidly increasing as it is more compatible with higher living standards, traffic safety and greater traffic volume. Color pavement application volume has been soaring particularly since 2003 when Children Protection Zone and bus lanes were designated in Seoul.

New materials and more sophisticated construction technique are the answers to cope with the defects witnessed in the existing color pavement methods, hence satisfy the surging demand for color pavement. 


\section{DEVELOPMENT OF MELTING-BLOWN ULTRA-THIN LAYER COLOR PAVEMENT TECHNIQUE}

\subsection{Outline}

Color pavement is currently widely applied in bus lanes, Children Protection Zones and accident-prone road sections in order to enhance road functions, secure visibility and boost city's aesthetic designs.

As a solution to the frequent defects witnessed in color pavements, a domestic manufacturer developed ultra-thin layer color pavement composite and its construction technique with basic reference into melting-blown paint technique for road marking. The ultimate objective, however, is to develop a method that satisfies color maintenance, skid resistance, durability, economics and construction property. This is where ultra-thin layer color pavement method comes into play. Its development to construct fast drying color composite materials in ultra-thin layer $(1.7 \sim 2.5 \mathrm{~mm})$ will help achieve the listed objectives and secure permeability for it to be applied to drainage pavements as well.

\subsection{Melting-blown ultra-thin layer color pavement}

In color pavement, which is developed based on melting-type paint technique for road marking, powder-type materials consisting of main aggregates including ceramic crystals, silicon, oil resin, rubberbased resin, wax, plasticizer and fill at $180 \sim 200{ }^{\circ} \mathrm{C}$ are heated and melted for a simple one-time construction at the site. In addition to the ease and simplicity, it creates a color that goes well with the surrounding environment when the right amount of appropriate pigment is mixed into the composite material. Color pavement using heat and meltingblown composite hardens within as short as $15 \sim 20$ minutes after construction, which does not seriously disrupt traffic and the materials melted at higher temperature of $180 \sim 200{ }^{\circ} \mathrm{C}$ melt asphalt to substantial extent when in immediate contact with asphalt roads, thus becoming consolidated. This, combined with materials' staunch adhesive strength, helps solve film stripping and separation of aggregate. Table 1 and Table 2 show composite elements and quality specifications.
Table 1. Composite Elements and Scope of Application

\begin{tabular}{|c|c|c|c|}
\hline List & $\begin{array}{c}\text { Scope of } \\
\text { Application }\end{array}$ & Main Materials & $\begin{array}{c}\text { Scope of } \\
\text { Application }\end{array}$ \\
\hline $\begin{array}{c}\text { Bonding } \\
\text { agents }\end{array}$ & $20 \pm 5 \%$ & $\begin{array}{c}\text { Oil resin } \\
\text { Plasticizer } \\
\text { Rubber-based } \\
\text { resin }\end{array}$ & $15 \pm 5 \%$ \\
$1 \sim 5 \%$ \\
Fill & $60 \pm 5 \%$ & $\begin{array}{c}\text { Limestone } \\
\text { Limestone } \\
\text { aggregate }\end{array}$ & $25 \pm 5 \%$ \\
\hline Pigment & $1 \sim 5 \%$ & $35 \pm 5 \%$ \\
\hline $\begin{array}{c}\text { Hard } \\
\text { aggregate }\end{array}$ & $15 \pm 5 \%$ & $\begin{array}{c}\text { Ceramic } \\
\text { aggregate(or } \\
\text { silicon) }\end{array}$ & $15 \pm 5 \%$ \\
\hline
\end{tabular}

Table 2. Quality Specification of Composites

\begin{tabular}{|c|c|}
\hline List & Quality Specification \\
\hline Gravity $\left(20^{\circ} \mathrm{C}\right)\left(\mathrm{g} / \mathrm{cm}^{3}\right)$ & Below 2.3 \\
\hline Softening point $\left({ }^{\circ} \mathrm{C}\right)$ & Above 80 \\
\hline $\begin{array}{c}\text { Print resistance drying } \\
\text { property } \\
\text { (Tire adherence) }\end{array}$ & $\begin{array}{l}\text { Film should not adhere after } \\
\text { more than } 3 \text { min. }\end{array}$ \\
\hline \begin{tabular}{|c|}
$\begin{array}{c}\text { Abrasion resistance }(\mathrm{mg}) \\
\text { (for } 100 \text { revolutions) }\end{array}$ \\
\end{tabular} & Below 200 \\
\hline $\begin{array}{l}\text { Compressive } \\
\text { strength }\left(\mathrm{kg} / \mathrm{cm}^{2}\right)\end{array}$ & Above 120 \\
\hline Alkali resistance & $\begin{array}{l}\text { There should be no cracks or } \\
\text { discoloration even after } \\
\text { digesting into potassium } \\
\text { hydroxide saturated solution } \\
\text { for } 18 \text { hours }\end{array}$ \\
\hline $\begin{array}{c}\text { Hard aggregate content } \\
(\text { mass \%) }\end{array}$ & $13.5 \sim 16.5$ \\
\hline $\begin{array}{c}\text { Particle diameter }(\mathrm{mm}) \\
\text { of hard aggregate content }\end{array}$ & $\begin{array}{l}\text { Colored porcelain aggregate } \\
\text { and natural hard aggregate } \\
\qquad 0.85 \sim 0.35\end{array}$ \\
\hline
\end{tabular}




\subsection{Melting-blown ultra-thin layer color pavement construction equipment}

Equipment used to construct melting-blown ultrathin layer color pavement is a modified version of equipment for road marking. The equipment is composed of "hopper," which keeps the melted paint warm, "spray," which sprays paint inside hopper onto road surface, "distributor," which distributes hard aggregate before it gets hard and "motor." Spray's two-wheeled revolving device, in particular, helps pave with consistent thickness. The construction equipment is shown in Figure 1.

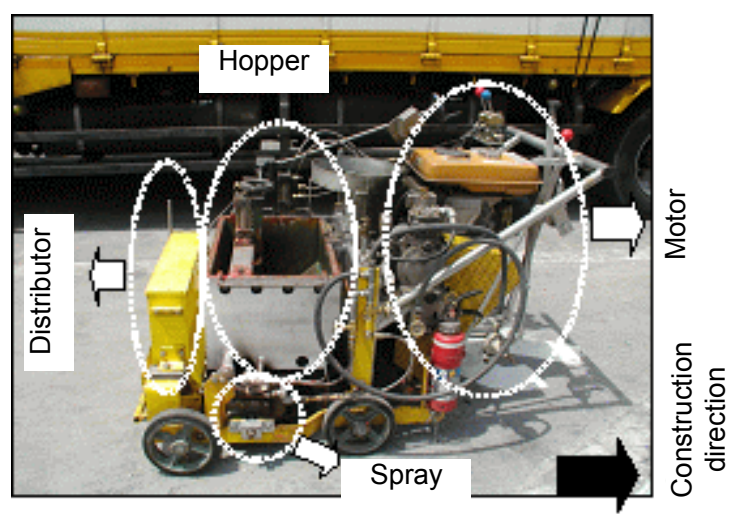

Figure 1. Melting-blown color pavement construction equipment

Materials inside the hopper flow into revolving device (roller) when shutter within the hopper is opened with the shutter lever, which with the centrifugal force and repelling power are then sprayed onto road surface. At the same time, aggregate, which is sprayed from aggregate distributor box installed in machine transmission, is distributed onto the unhardened films.

\subsection{Melting-blown ultra-thin layer color pavement construction method}

Construction machine exclusive only to meltingblown color pavement construction sprays meltingtype paint onto roads with a consistent thickness and bind distributing aggregate onto road textures when still in unhardened condition.
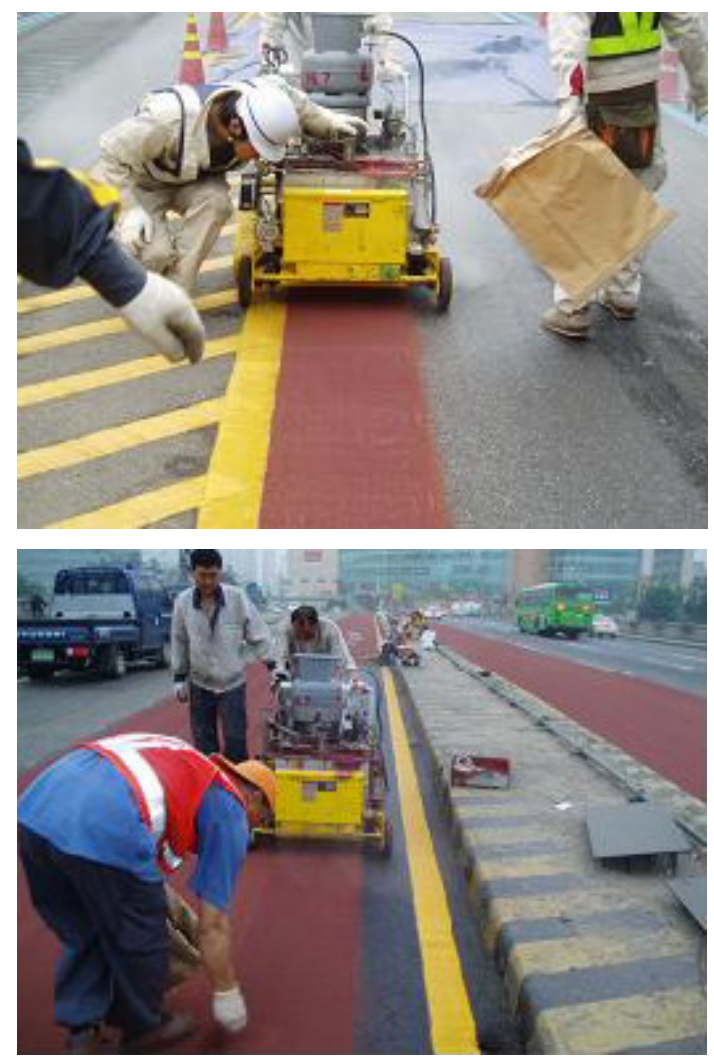

Figure 2. Melting-blown ultra-thin layer color pavement construction

Paint mixed and melted in a separate melting pot at $180 \sim 200 \square$ is first delivered to the hopper (for keeping materials warm) in the exclusive construction machine. Certain amount of the materials is then delivered to spray by controlling the handle lever to open/lock shutter inside the hopper. Centrifugal force and repelling power of spray's revolving roller (gear roller) then sprays fog-type paints onto roads. At the same time, as distributing aggregate is tied to the handle lever, aggregate is distributed and bound to the pavement texture when the shutter is opened and connected to the driving wheel. It then cools down and hardens (see Figure 2).

Since it is a motorized type running on engine, the speed and application volume are both consistent, thus enabling to form a consistent thickness. 
Revolving roller in the spray has two axes and the $1: 1$ high-speed revolution spouts only certain amount of the melted spray-type paint.

\section{PERFORMANCE EVALUATION OF MELTING-BLOWN ULTRA-THIN LAYER COLOR PAVEMENT}

\subsection{Performance evaluation of composite}

Composite used for this particular construction method has been developed from melting-blown paint technique for road marking. Accordingly, test items and methods for melt jointing type paint for road marking specifications (KS M5333) have been employed as the basis to evaluate the performance of composite properties for melting-blown ultra-thin layer color pavement.

\subsection{Hardening speed}

Tire adherence test was carried out to check the time taken to harden composite and the temperature changes (see Table 3).

In compliance with the test methods for paint and other related raw materials, temperature was checked and tire adherence test was conducted every 30 seconds from the point of composite application in order to monitor the hardening process and time.

Test results showed that temperature of film fell sharply to $114{ }^{\circ} \mathrm{C}$ immediately after application.

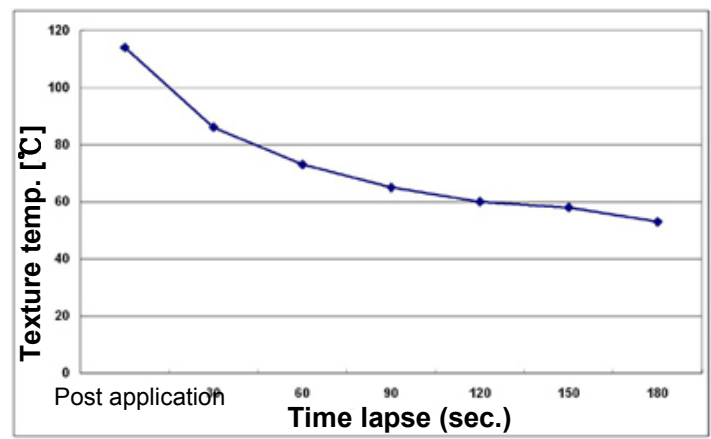

Figure 3. Changes in the texture temperature after spraying composite

Paint adherence to the tire was witnessed within one minute from application but not from $1 \mathrm{~min} .30 \mathrm{sec}$. Tire marks were hardly visible from $2 \mathrm{~min}$. and longer. Test was concluded after more than $3 \mathrm{~min}$. from application when texture temperature dropped to 53. Figure 3 shows the changes in the texture temperature after spraying composite. Figure 4 shows texture's condition after the test.

Table 3. Test results for composite properties

\begin{tabular}{|c|c|c|c|}
\hline \multicolumn{2}{|c|}{ 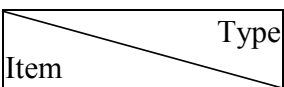 } & Standards & Result \\
\hline \multicolumn{2}{|c|}{ Gravity $\left(20 / 20^{\circ} \mathrm{C}\right)$} & Below 2.3 & 2.1 \\
\hline \multicolumn{2}{|c|}{ Softening pt. $\left({ }^{\circ} \mathrm{C}\right)$} & Above 80 & 91 \\
\hline \multicolumn{2}{|c|}{$\begin{array}{l}\text { Print resistance } \\
\text { drying property }\end{array}$} & $\begin{array}{c}\text { Paint should not adhere } \\
\text { to print resistance } \\
\text { tester's tire after more } \\
\text { than } 3 \text { min. } \\
\end{array}$ & Normal \\
\hline \multicolumn{2}{|c|}{ Film exterior } & $\begin{array}{l}\text { There should be no } \\
\text { wrinkles, stain, } \\
\text { swelling, crack and } \\
\text { fall-off }\end{array}$ & Normal \\
\hline \multicolumn{2}{|c|}{ Abrasion resistance } & $\begin{array}{l}\text { Less than } 200 \mathrm{mg} \text { per } \\
100 \text { revolution }\end{array}$ & 71 \\
\hline \multicolumn{2}{|c|}{$\begin{array}{c}\text { Compressive strength } \\
\left(\mathrm{KN} / \mathrm{cm}^{2}\right)\end{array}$} & Above 1,100 & 1.582 \\
\hline \multicolumn{2}{|c|}{ Alkali resistance } & \begin{tabular}{|c|} 
There should be no \\
cracks or discoloration \\
even after digesting \\
into potassium \\
hydroxide saturated \\
solution for 18 hours \\
\end{tabular} & Normal \\
\hline \multirow{2}{*}{$\begin{array}{l}\text { Accelerated } \\
\text { weathering }\end{array}$} & Exterior & \multirow{2}{*}{$\begin{array}{c}\text { No cracking, swelling } \\
\text { and fall-off, etc., after } \\
160 \text { hours of } \\
\text { accelerated weathering } \\
\text { test. No more than } 6 \\
\text { units in color } \\
\text { luminosity difference }\end{array}$} & Normal \\
\hline & $\begin{array}{c}\text { Color } \\
\text { change }\end{array}$ & & 0.4 \\
\hline \multicolumn{2}{|c|}{$\begin{array}{c}\text { Nonvolatile content } \\
(\%)\end{array}$} & Above 99 & 99 \\
\hline \multicolumn{2}{|c|}{$\begin{array}{c}\text { Lead ( } \% \text { of } \\
\text { nonvolatile content) } \\
\end{array}$} & Below 0.06 & $\begin{array}{l}\text { Not } \\
\text { found }\end{array}$ \\
\hline \multicolumn{2}{|c|}{$\begin{array}{c}\text { Cadmium ( } \% \text { of } \\
\text { nonvolatile content) }\end{array}$} & Below 0.01 & $\begin{array}{l}\text { Not } \\
\text { found }\end{array}$ \\
\hline \multicolumn{2}{|c|}{$\begin{array}{c}\text { Nonvolatile vehicle } \\
\text { (\% of paint) }\end{array}$} & Above 20 & 21 \\
\hline
\end{tabular}




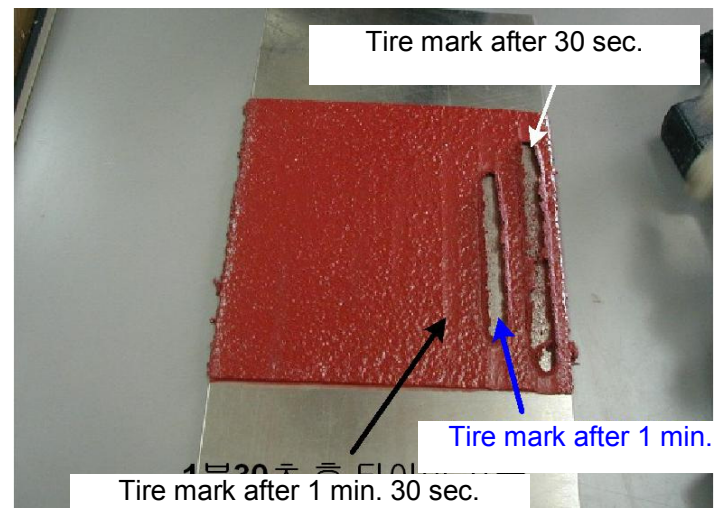

Figure 4. Post-test texture condition

Ultra-thin layer color pavement has been developed with basic reference into melt jointing type paint for road marking and its basic performance is designed to meet the specifications of road marking paint. Therefore, it also complies with the tire adherence test, which specifies that paint shall not adhere to tire after three minutes from application at the longest so that the road does not have to suffer from inconveniences from traffic restriction for too long (see Figure 5).

\subsection{Skid resistance test}

Skid resistance test was taken in accordance with the skid resistance test criteria and methods under KS F 2375, which uses British Pendulum Test either in a lab or outdoors to measure friction of micro texture.

Indoor test was carried out with a texture manufactured for test purposes and outdoor test was carried out at the site constructed in Nov., 2007. Skid resistance of a dense pavement nearby the constructed section was measured for comparative evaluation. Indoor test results and site test results are shown in Table 4 and Table 5.

There is no related regulation imposed to skid resistance in Korea other than the minimum standards of coefficient of friction suggested in the Anti-slippery Pavement Chapter of 'Establishment of Road Safety Facilities and Management Guidelines' published by the former Ministry of Constructions \& Transportation. Given that the minimum coefficient of friction demanded for most accident-prone sections in highest-graded roads, according to the Anti-slippery Pavement Chapter, is 77 BPN, skid resistance as shown in the test results of melting-blown ultra-thin layer color pavement both indoor and outdoor is considered to be excellent.

Table 4. Skid Resistance Test Result (Indoor)

\begin{tabular}{|c|c|c|}
\hline No. & Skid resistance coefficient $(\mathrm{BPN})$ & Test temperature $(\square)$ \\
\hline 1 & 72 & 23 \\
\hline
\end{tabular}

Table 5. Skid Resistance Site Test Result

\begin{tabular}{|c|c|c|c|c|}
\hline $\begin{array}{c}\text { Construction } \\
\text { section }\end{array}$ & \multicolumn{2}{|c|}{$\begin{array}{c}\text { Ultra-thin layer } \\
\text { color pavement }\end{array}$} & \multicolumn{2}{|c|}{ Dense pavement } \\
\hline & BPN & $\begin{array}{c}\text { Test } \\
\text { temperature } \\
\left({ }^{\circ} \mathrm{C}\right)\end{array}$ & $\mathrm{BPN}$ & $\begin{array}{c}\text { Test } \\
\text { temperature } \\
\left({ }^{\circ} \mathrm{C}\right)\end{array}$ \\
\hline $\mathrm{A}$ & 74 & 12 & 63 & 10 \\
\hline $\mathrm{B}$ & 68 & 27 & 47 & 25 \\
\hline $\mathrm{C}$ & 67 & 27 & 43 & 25 \\
\hline
\end{tabular}

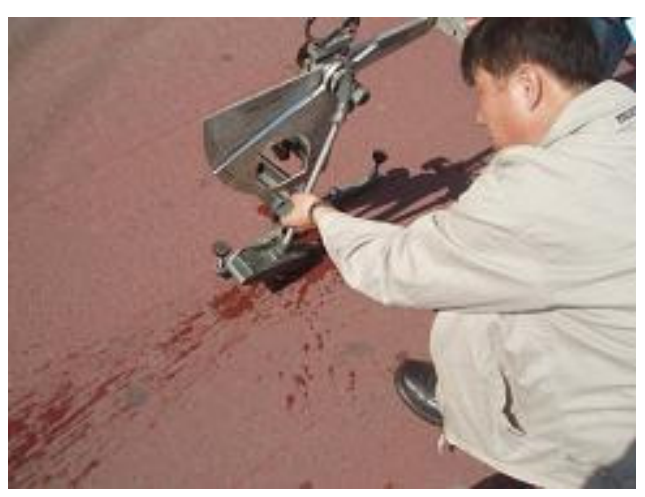

Figure 5. Skid resistance test on-site

\subsection{Adhesion intensity}

Adhesion intensity test evaluates the properties that help maintain adhesive strength between the existing pavement and ultra-thin layer color pavement. Adhesion intensity test method for KS M 3718 adhesives was employed for the test (see Figure 6). 

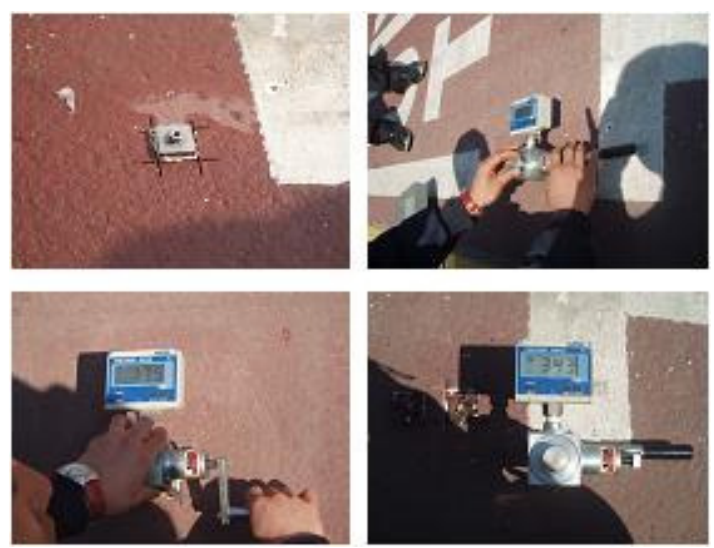

Figure 6. Adhesion intensity site test

Table 6. Adhesion intensity test results

\begin{tabular}{|c|c|c|c|}
\hline Classification & Point 1 & Point 2 & Point 3 \\
\hline Adhesive strength $(\mathrm{kg} \mathrm{f})$ & 384 & 343 & 401 \\
\hline Adhesion intensity $\left(\mathrm{kg} \mathrm{f} / \mathrm{cm}^{2}\right)$ & 24.0 & 21.4 & 25.1 \\
\hline Mean value $\left(\mathrm{kg} \mathrm{f} / \mathrm{cm}^{2}\right)$ & \multicolumn{3}{|c|}{$\mathbf{2 3 . 5}$} \\
\hline
\end{tabular}

Site test results for adhesion intensity was an average of $23.5 \mathrm{kgf} / \mathrm{cm}^{2}$, which sufficiently satisfies the adhesion intensity standards (above $12 \mathrm{kgf} / \mathrm{cm}^{2}$ ) for asphalt pavement and resin bonding agents as suggested in the Other Safety Facilities Chapter of 'Establishment of Road Safety Facilities and Management Guidelines' published by the former Ministry of Constructions \& Transportation. The test results are satisfactory enough to conclude that defects such as film stripping will be substantially alleviated and color pavements will live up to their functions when assuming that asphalt pavements are free of defects (see Table 6).

\subsection{Permeability performance}

Permeability test evaluates the properties that help maintain permeability when this technique is applied to drainage pavement and permeability pavement on roadways and sidewalks. The test was carried out in accordance with the indoor permeability test method of KS F 2494 drainage asphalt mixture.

The test followed indoor evaluation method of drainage asphalt mixture's permeability to compare the permeability test results before \& after application of melting-blown ultra-thin layer color pavement method, thereby evaluate the performance (see Figures 7, 8).

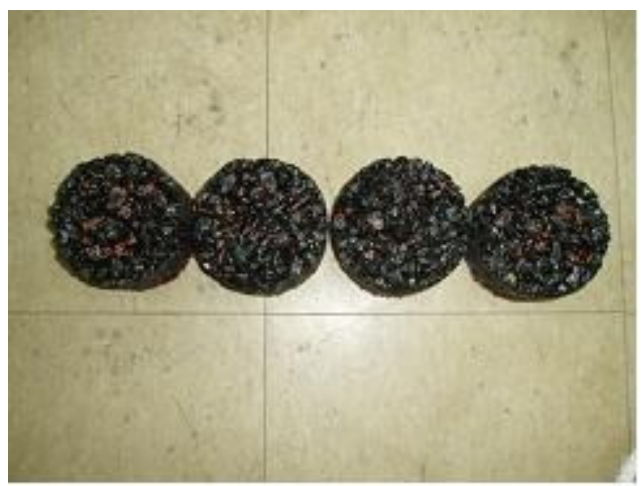

Before application

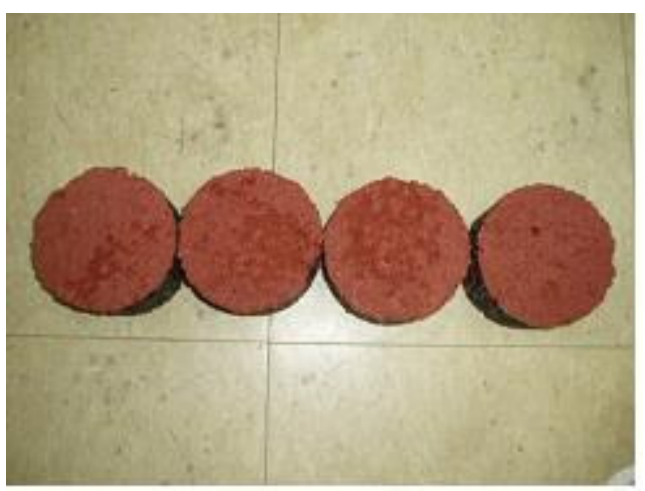

After application

Figure 7. Composite spray into specimen Before \& After

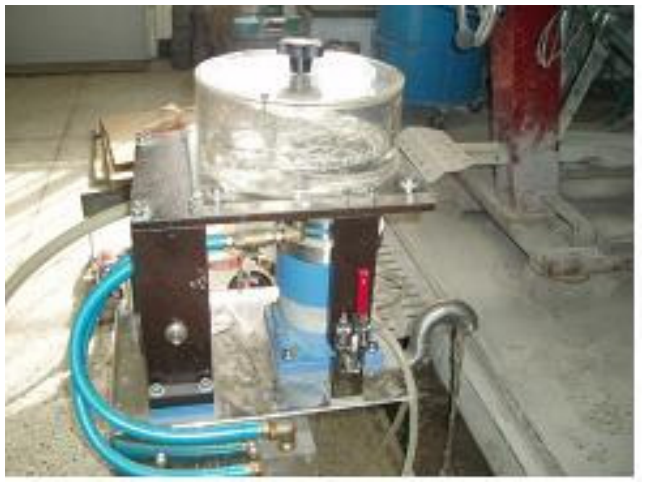

Figure 8. Indoor Permeability Test Equipment 
Permeability test on melting-blown color pavement before and after application showed that over $80 \%$ in permeability rate is maintained. Test results are in Table 6.

Table 6. Indoor Permeability Test Results

\begin{tabular}{|c|c|c|c|c|c|}
\hline \multirow[b]{2}{*}{ No } & \multicolumn{2}{|c|}{ Before application } & \multicolumn{2}{|c|}{ After application } & \multirow{2}{*}{$\begin{array}{c}\text { Permeabilit } \\
\text { Rate } \\
(\%)\end{array}$} \\
\hline & $\begin{array}{c}\text { Output } \\
\text { vol. } \\
(\mathrm{g} / \mathrm{sec})\end{array}$ & $\begin{array}{c}\text { Coefficient of } \\
\text { permeability } \\
(\mathrm{cm} / \mathrm{sec})\end{array}$ & $\begin{array}{c}\text { Output } \\
\text { vol. } \\
(\mathrm{g} / \mathrm{sec})\end{array}$ & $\begin{array}{c}\begin{array}{c}\text { Coefficient of } \\
\text { permeability }\end{array} \\
(\mathrm{cm} / \mathrm{sec})\end{array}$ & \\
\hline 1 & 110.4 & 0.315 & 89.0 & 0.267 & 80.6 \\
\hline 2 & 106.2 & 0.305 & 84.2 & 0.254 & 79.3 \\
\hline 3 & $\mid 117.1$ & 0.333 & 93.3 & 0.278 & 79.7 \\
\hline 4 & 91.1 & 0.259 & 79.3 & 0.237 & 87.0 \\
\hline 5 & \begin{tabular}{|l|}
107.2 \\
\end{tabular} & 0.302 & 88.3 & 0.260 & 82.4 \\
\hline 6 & \begin{tabular}{|l|}
102.8 \\
\end{tabular} & 0.295 & 90.4 & 0.271 & 87.9 \\
\hline $\mathrm{AVG}$ & & & & & 82.8 \\
\hline
\end{tabular}

The test results lead to the conclusion that this method will perform its function even when applied to drainage pavement sections.

\section{CONCLUSION}

Color pavement is being widely applied these days to improve aesthetic cityscape and warn accidentprone sections to drivers. Yet, its technique employed in Korea has defects, namely separation of aggregate, suspension of pigments and texture decolorization. This certainly requires a more advanced color pavement technique that helps remove such defects and meet social needs.
This treatise examined how composites for ultra-thin layer color pavement, which is developed from melting-blown paint technique for road making, are manufactured and its construction techniques. It also analyzed the performance evaluation results of pavement methods employed with the same technique.

Ultra-thin layer color pavement is constructed with relatively simple equipment. Its biggest strengths are quick hardening, which keeps traffic restrictions to a minimum, small number of necessary manpower, low-temperature construction and wide range of color choice. Its performance evaluation results all exceeded the standards stipulated in the related regulations and skid resistance was also evaluated to excel other existing pavements.

The development of this method was aimed at overcoming defects frequently witnessed in the existing methods. As such, its advanced and environmentally-friendly technique that helps prevent car accidents will hopefully bring about favorable economic and social impact.

\section{REFERENCE}

[1] Ministry of Construction and Technology (1997), Highway Safety Facilities installation \& Maintenance Manual.

[2] Korea Road \& Transportation Association (1997), Asphalt Pavement Design \& Construction Manual 